\title{
Effect of immunosuppression on arthritis in mice induced by Mycoplasma pulmonis
}

\author{
GERALDINE TAYLOR, D. TAYLOR-ROBINSON, AND G. SLAVIN \\ M.R.C. Clinical Research Centre and Northwick Park Hospital, Harrow, Middlesex
}

In contrast to the unknown role of mycoplasmas in the pathogenesis of rheumatoid arthritis, it is known that they produce arthritis both naturally and experimentally in a variety of other animals. For example, Mycoplasma hyorhinis and Mycoplasma granularum cause arthritis in swine (Ross and Switzer, 1968; Switzer, 1969; Barden and Decker, 1971), Mycoplasma gallisepticum and Mycoplasma synoviae cause arthritis in turkeys and chickens (Olson, Kerr, and Campbell, 1964; Fabricant, 1969), and Mycoplasma arthritidis and Mycoplasma pulmonis cause arthritis in rats and mice (Findlay, Mackenzie, MacCallum, and Klieneberger, 1939; Cole, Ward, Jones, and Cahill, 1971; Barden and Tully, 1969). In rats, $M$. arthritidis produces an acute short-term infection, but in mice infection with this mycoplasma results in a chronic arthritis which persists for at least 9 months (Cole and others, 1971). These authors suggested that the course and histopathology of the chronic phase of this arthritis closely resembles that of rheumatoid arthritis. Likewise, Barden and Tully (1969) reported that mice infected with $M$. pulmonis developed a chronic arthritis, joint enlargement occurring for up to 4 months after intravenous inoculation. However, the mechanisms involved in the production of these various arthritides are unknown.

Denny, Taylor-Robinson, and Allison (1972) have shown that a thymus-dependent function is important for the development of pneumonia in mice infected intranasally with $M$. pulmonis, and a similar mechanism is involved in the development of pneumonia in hamsters inoculated intranasally with Mycoplasma pneumoniae Taylor, Taylor-R binson, and Fernald, 1974). Because of these observations, we have attempted to determine to what extent the pathological features of the arthritis produced by $M$. pulmonis in mice are dependent upon immunological mechanisms and have examined the effect on the arthritis of immunosuppressing mice by thymectomy and by cyclophosphamide treatment.

\section{Materials and methods}

M. pulmonis

Strain 'JB' was obtained from Mr. P. C. T. Hannan as a broth culture after three in vitro passages from the original provided by Dr. J. Tully. The broth culture was inoculated into thallium acetate-free medium and this was incubated $>$ at $37^{\circ} \mathrm{C}$ for 3 days after which it was dispensed in $1 \mathrm{ml} \overrightarrow{\vec{\theta}}$ amounts and stored at $-70^{\circ} \mathrm{C}$. Dilutions of this stock culture, which contained $10^{8}$ colour-changing units (ccu)/ $\mathrm{ml}$, were made in PPLO broth and used as inocula for mice.

\section{Mice}

Young adult male $\mathrm{CBA}$ and $\mathrm{C} 3 \mathrm{H}$ mice, weighing $20-30 \mathrm{~g}$, were used in all experiments and were kept in isolation. They were obtained from several sources as specific pathogen-free animals and were found to be free of detectable mycoplasmas in the nasopharynx before use. The mice were thymectomized at 3-4 weeks of age and 2 weeks later received $850-900 \mathrm{r}$ whole body $x$-irradiation, followed by at least $10^{6}$ syngeneic bone marrow cells injected intravenously on the same day as the irradiation. In other experiments mice were inoculated intraperitoneally with a single dose of $300 \mathrm{mg}$ cyclophosphamide/ $\mathrm{kg}$ body weight (Turk and Poulter, 1972) at various times before and after inoculation of the mycoplasmas.

Induction of arthritis and assessment of severity Three to 7 weeks after irradiation mice were infected by intravenous inoculation of $0.2 \mathrm{ml}$ of the stock mycoplasma culture or dilutions thereof. Mice used as controls were inoculated with $0.2 \mathrm{ml}$ PPLO broth.

Subjective assessment of the severity of the arthritis was made by scoring the swelling of each joint from 1 to 3 . Scores for groups of mice were totalled, divided by the number of animals in each group, and recorded as the 'arthritis score'.

\section{Mycoplasma medium}

Liquid medium for the isolation and growth of $M$.pulmonis consisted of Difco PPLO broth $(70 \mathrm{ml}), 25 \%$ extract of dried yeast (Distillers Co. Ltd.) $(10 \mathrm{ml})$, unheated Burroughs Wellcome horse serum no. $6(20 \mathrm{ml}), 0.1 \%$ glucose, $0.002 \%$ phenol red, 1:2000 thallium acetate and 
penicillin $\mathrm{G}(1,000$ units $/ \mathrm{ml})$. The $\mathrm{pH}$ of the medium was adjusted to $7 \cdot 8$.

\section{Mycoplasma isolation procedures}

Mice were anaesthetized at various intervals after mycoplasma inoculation by intraperitoneal injection of sodium pentobarbitone and then they were bled out from the axillary vessels. Swabs of the pharynx, washings of the lungs (Taylor-Robinson, Denny, Thompson, Allison, and Mårdh, 1972), and specimens of blood, liver, spleen, and brain were collected. In addition, the left ankle joint from each mouse was removed. Surgical instruments were sterilized between sampling different organs. The solid tissues, including joints, were homogenized in TenBroek grinders with mycoplasma medium to give $10 \%(\mathrm{w} / \mathrm{v})$ suspensions as described by Denny and others (1972).

Isolation and titration of mycoplasmas present in the various specimens were carried out by making a series of tenfold dilutions of the specimens in $1.8 \mathrm{ml}$ of mycoplasma medium contained in $2 \mathrm{ml}$ screw-capped vials. The vials were incubated at $37^{\circ} \mathrm{C}$ for at least 2 weeks. During this time they were observed for a colour change of the medium from pink to yellow, this being an indication of multiplication of the organisms. The highest dilution causing such a change was considered to contain one ccu. Isolated organisms were identified as $M$. pulmonis by the metabolisminhibition test (see below).

\section{Histological procedures}

Lungs, liver, spleen, brain, and joints were fixed in $10 \%$ formolsaline. Joints were decalcified overnight in $10 \%$ formic acid. After fixation, the tissues were embedded in paraffin wax, sectioned, and stained with haematoxylin and eosin. Some joints were also stained by the picroMallory method for detection of fibrin.

\section{Metabolism-inhibition test}

The micro-technique of Taylor-Robinson, Purcell, Wong, and Chanock (1966) was used to determine the antibody titre of sera from infected mice. These sera were inactivated at $56^{\circ} \mathrm{C}$ for 30 mins before use. Unheated guinea pig serum was used at a final concentration of $1 \%(\mathrm{v} / \mathrm{v})$. The results were recorded when a colour change equivalent to about $0.5 \mathrm{pH}$ unit had occurred in the wells containing mycoplasma only.

The $\gamma$-globulins in mouse sera were concentrated tenfold in the following manner: sera were treated with $33 \%$ saturated ammonium sulphate and the resulting precipitates were washed three times and redissolved in Tris buffer at $\mathrm{pH} 7 \cdot 8$. The redissolved precipitates were then dialysed at $4^{\circ} \mathrm{C}$ against Tris buffer and concentrated to one-tenth their original volume by using an Amicon microultrafiltration/dialysis unit with a Diaflow UM 10 membrane.

\section{Results}

Factors concerned in development of arthritis in immunologically normal mice

EFFECT OF DIFFERENT NUMBERS OF $M$. pulmonis ORGANISMS

Barden and Tully (1969) reported that greater and more rapid joint enlargement occurred by increasing the number of mycoplasma organisms in the challenge inocula. We inoculated $10^{7}, 10^{5}, 10^{3}$, and 10 organisms of $M$. pulmonis into $\mathrm{C} 3 \mathrm{H}$ mice in groups of five. Neither mycoplasma medium alone nor the inoculum containing 10 organisms produced joint enlargement. However, larger numbers of organisms caused arthritis and, as shown in Fig. 1, by increasing the number of mycoplasmas inoculated, the maximum arthritis score was increased and the number of days taken to achieve this maximum was decreased.

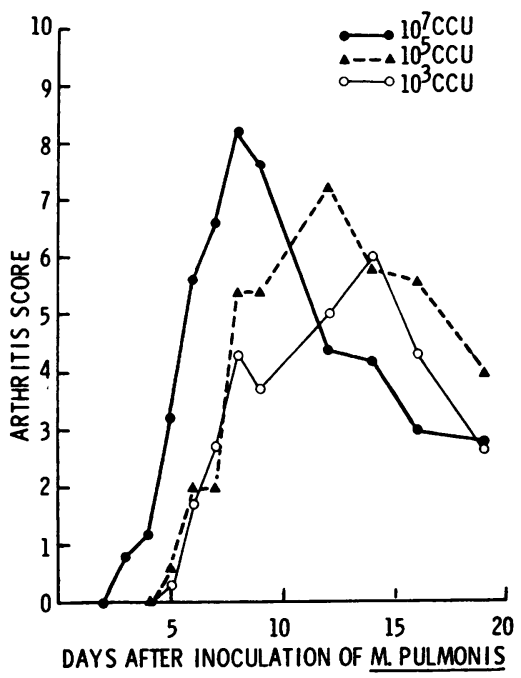

FIG. 1 Effect of different numbers of M. pulmonis organisms on the development of arthritis, expressed as an arthritis score, in $\mathrm{C} 3 \mathrm{H}$ mice. $\mathrm{ccu}=$ colour-changing units

\section{EFFECT OF DIFFERENT STRAINS OF MICE}

The development of arthritis differs with the strain of mouse used (Hannan, 1971). We have not only observed that $\mathrm{C} 3 \mathrm{H}$ mice develop a more severe arthritis than CBA mice (Fig. 2) as judged by the arthritis score, but we have also noted that scores for any one strain may vary from one experiment to another.

\section{$T$-cell depletion in mice infected with $\mathrm{M}$. pulmonis}

EFFECT ON ARTHRITIS SCORE

Thymectomized and $x$-irradiated mice, which are deficient in their cell-mediated immunity, are commonly referred to as ' $B$ ' mice. Mice immunosuppressed in this way and immunologically normal mice were inoculated intravenously with approximately $10^{6} \mathrm{ccu}$ of $M$. pulmonis. Altogether four experiments were done in which a total of 35 immunosuppressed mice and a similar number of normal control mice were used. The rate of development and resolution of the arthritis varied from experiment to experiment, but it was apparent, as shown in Fig. 3, that the ' $B$ ' mice developed a more severe arthritis 


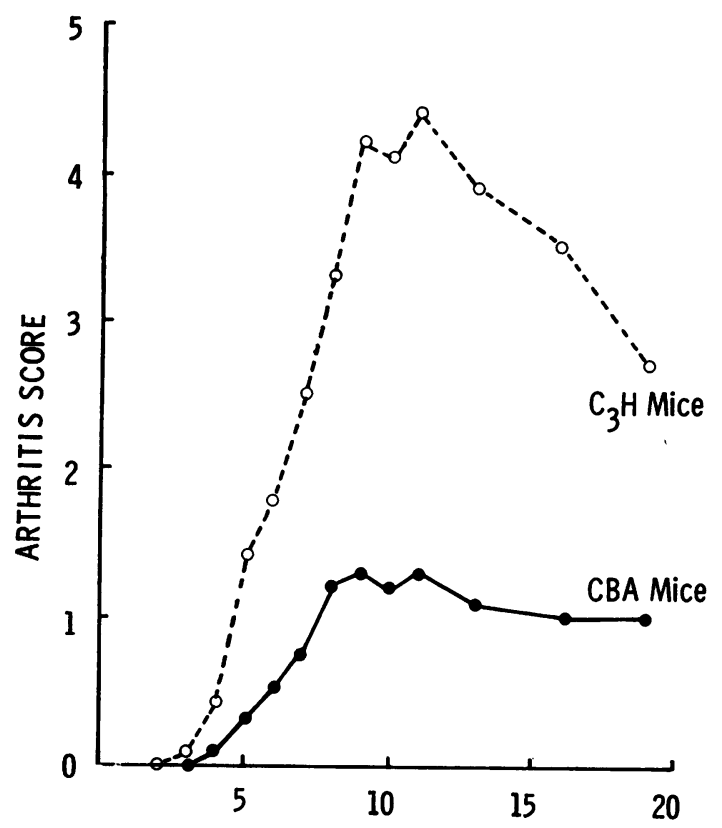

DAYS AFTER INOCULATION OF M. PULMONIS

FIG. 2 Comparison of arthritis scores for $C 3 H$ and $C B A$ mice inoculated with $10^{6} \mathrm{ccu}$ of $\mathrm{M}$. pulmonis

than the immunologically normal mice but that it resolved at about the same rate. The greater arthritis score of the ' $B$ ' mice was not only due to greater enlargement of individual joints, but also to an increase in the number of joints involved.

\section{EFFECT ON HISTOPATHOLOGY}

The types of cells in the joints of immunosuppressed mice were the same as those in the joints of immunologically normal mice as seen 6 to 10 days after inoculation. That is, there was about an equal mixture of polymorphonuclear leucocytes and monocytes (Fig. 4). However, the inflammatory response was slightly more marked in the joints of immunosuppressed $\underline{ }$

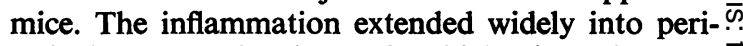
articular connective tissues, in which micro-abscesses $\overrightarrow{\overrightarrow{\vec{S}}}$ sometimes were seen (Fig. 5). Joint spaces were in- $-\frac{\vec{\sigma}}{\sigma}$ volved to a lesser extent (Fig. 6), the inflammatory reaction, when it occurred, being exudative; poly- $\frac{\bar{c}}{\bar{s}}$ morphonuclear leucocytes were slightly more frequent than round cells. In addition, fibrin was present and some degenerative changes in the synovia were ${ }^{\text {s }}$ seen.

\section{EFFECT ON DISTRIBUTION AND NUMBER OF MYCOPLASMA ORGANISMS IN VARIOUS ORGANS} It was possible that the more severe arthritis of the ' $B$ ' mice was associated with greater numbers of $\vec{\omega}$ mycoplasmas in the affected joints. To determine this, immunosuppressed and immunologically nor-o mal mice were examined for mycoplasmas 10 days after inoculation, at which time the difference be- $\vec{c}$ tween the arthritis scores was usually greatest. As shown in Table I, M. pulmonis organisms were iso- $\vec{\bullet}$ lated from the joints of immunosuppressed mice usually more frequently than from the joints of normal mice. However, there was no difference in the numbers of organisms isolated from the joints of the immunosuppressed and normal mice.

At the same time the incidence of isolation of $\frac{0}{0}$

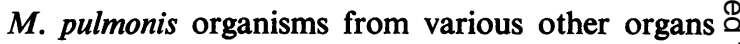
was studied. As shown in Table II, M. pulmonis was $\overrightarrow{\bar{O}}$ isolated about one and a half times more frequently $\exists$ from organs of immunosuppressed mice than from those of normal mice. However, the numbers of organisms isolated were similar in the two groups.

Cyclophosphamide treatment of mice infected with M. pulmonis

In an attempt to differentiate further between humoral and cell-mediated mechanisms, mice were $\circ$ inoculated with cyclophosphamide at various times before and after $M$. pulmonis infection.

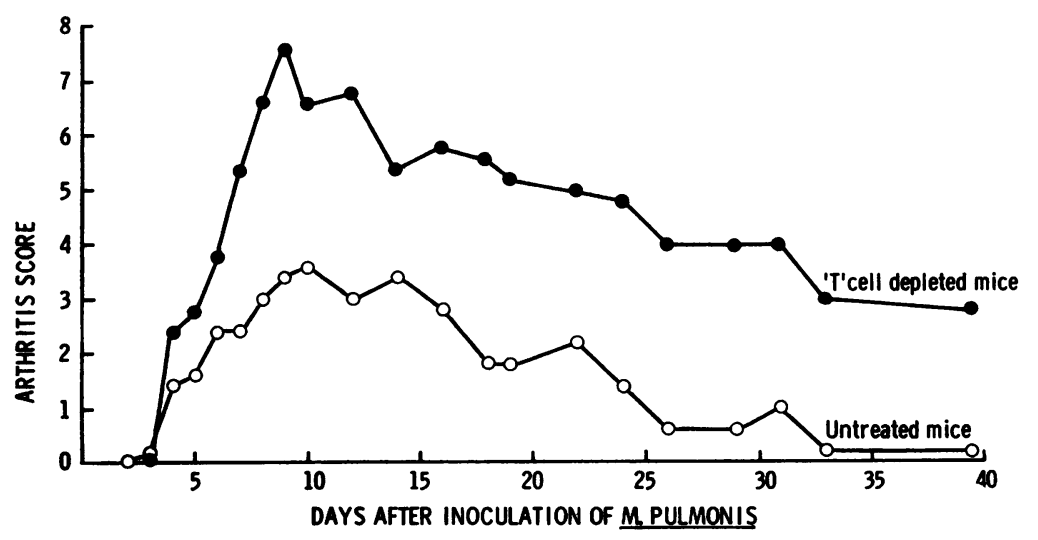

FIG. 3 Effect of thymectomy and $\mathrm{x}$-irradiation on the development of arthritis in mice inoculated with $10^{6} \mathrm{ccu}$ of $\mathrm{M}$. pulmonis 


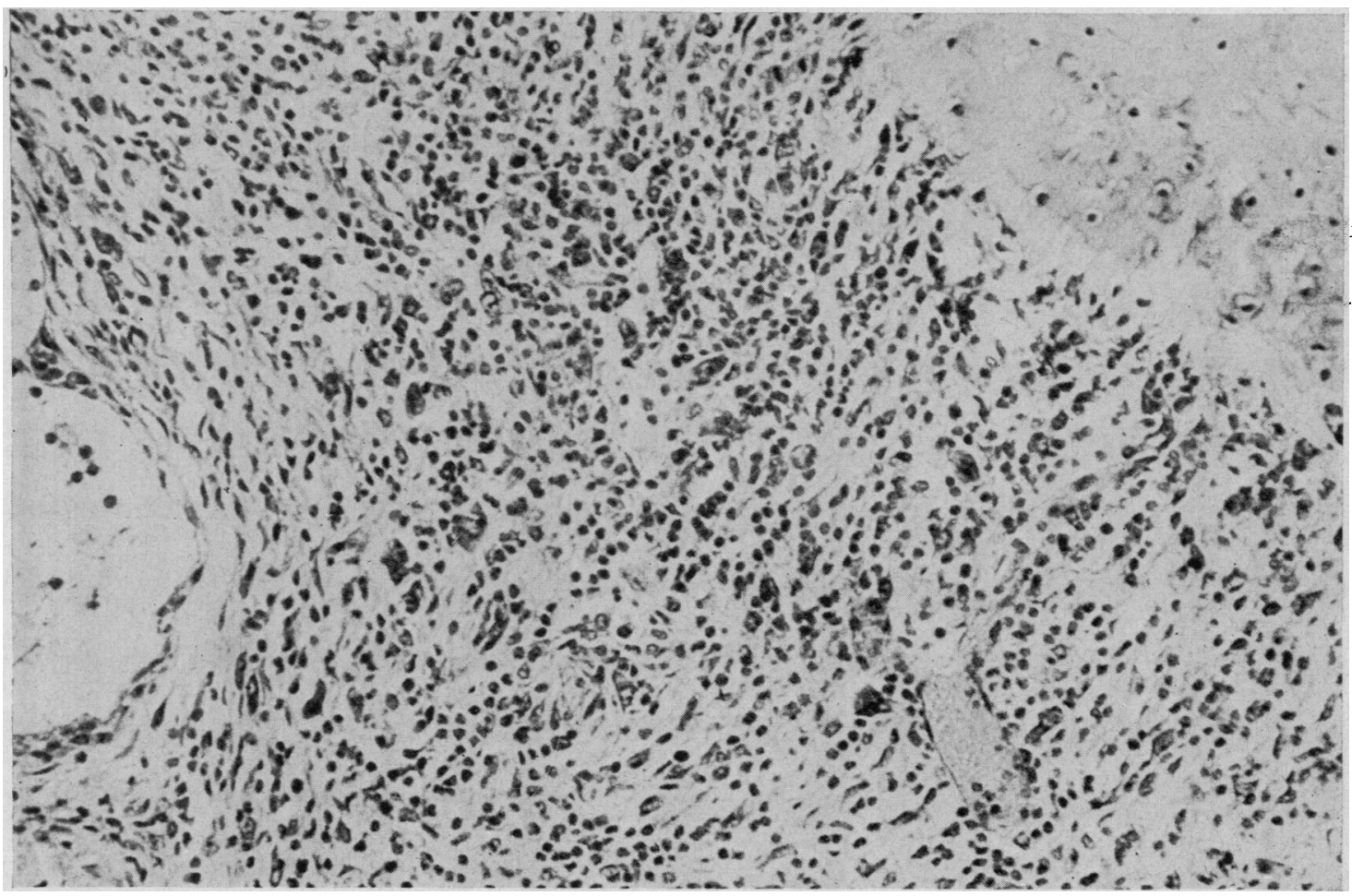

FIG. 4 Ankle joint from $a$ ' $B$ ' mouse 10 days after M. pulmonis infection, in which there is periarticular infiltration of polymorphonuclear leucocytes and monocytes. $\times 315$

Table I Effect of T-cell depletion on the isolation of $\mathrm{M}$. pulmonis from the joints of mice infected with this mycoplasma

\begin{tabular}{|c|c|c|c|}
\hline Experiment no. & Immune status of mice & $\begin{array}{l}\text { No. of isolations/ } \\
\text { no. of mice inoculated }\end{array}$ & $\begin{array}{l}\text { Geometric mean of no. of } \\
\text { organisms isolated }{ }^{*} \\
\left(\log _{10} \mathrm{ccu} / \mathrm{ml}\right)\end{array}$ \\
\hline $\begin{array}{l}1 \\
2 \\
3\end{array}$ & $\begin{array}{l}\text { Normal } \\
\text { Immunosuppressed } \\
\text { Normal } \\
\text { Immunosuppressed } \\
\text { Normal } \\
\text { Immunosuppressed }\end{array}$ & $\begin{array}{l}5 / 10 \\
8 / 8 \\
2 / 5 \\
5 / 5 \\
5 / 5 \\
4 / 5\end{array}$ & $\begin{array}{l}3 \cdot 2 \\
4 \cdot 4 \\
4 \cdot 5 \\
5 \cdot 4 \\
5 \cdot 6 \\
5 \cdot 2\end{array}$ \\
\hline
\end{tabular}

- Calculated for 'positive' mice only. ccu = colour-changing units.

Table II Effect of T-cell depletion on the isolation of M. pulmonis from mice infected with this mycoplasma

\begin{tabular}{|c|c|c|c|c|c|c|c|c|c|c|}
\hline \multirow{3}{*}{$\begin{array}{l}\text { Experiment } \\
\text { no. }\end{array}$} & \multirow{3}{*}{$\begin{array}{l}\begin{array}{l}\text { Immune status } \\
\text { of mice }\end{array} \\
\text { Normal }\end{array}$} & \multicolumn{8}{|c|}{ Mycoplasmas isolated from } & \multirow{3}{*}{$\begin{array}{l}\begin{array}{l}\text { Incidence of } \\
\text { mycoplasma } \\
\text { isolation } \\
(\%)\end{array} \\
28\end{array}$} \\
\hline & & \multicolumn{2}{|l|}{ Blood } & \multicolumn{2}{|l|}{ Liver } & \multicolumn{2}{|c|}{ Spleen } & \multicolumn{2}{|c|}{ Brain } & \\
\hline & & $\begin{array}{l}0 / 10^{*} \\
2 / 8\end{array}$ & $\begin{array}{l}(<1 \cdot 0) \dagger \\
(4 \cdot 0)\end{array}$ & $\begin{array}{l}1 / 10 \\
4 / 8\end{array}$ & $\begin{array}{l}(3 \cdot 0) \\
(4 \cdot 3)\end{array}$ & $10 / 10$ & $\begin{array}{l}(5 \cdot 1) \\
(4 \cdot 3)\end{array}$ & $0 / 10$ & $(<1 \cdot 0)$ & \\
\hline 2 & Normal & $0 / 5$ & $(<1 \cdot 0)$ & $1 / 5$ & $(4 \cdot 0)$ & $5 / 5$ & $(3 \cdot 6)$ & $1 / 5$ & $(3.0)$ & 35 \\
\hline & Immunosuppressed & $0 / 5$ & $(<1 \cdot 0)$ & $4 / 5$ & $(3 \cdot 2)$ & $5 / 5$ & $(5.0)$ & $2 / 5$ & $(3 \cdot 5)$ & 55 \\
\hline 3 & Normal & $0 / 5$ & $(<1 \cdot 0)$ & $0 / 5$ & $(<1 \cdot 0)$ & $5 / 5$ & $(4 \cdot 2)$ & $1 / 5$ & $(4 \cdot 0)$ & 30 \\
\hline
\end{tabular}

* Proportion of mice from which M. pulmonis was isolated after intravenous inoculation.

† Geometric mean of no. of organisms isolated $\left(\log _{10} \mathrm{ccu} / \mathrm{ml}\right)$ calculated for 'positive' mice only. 


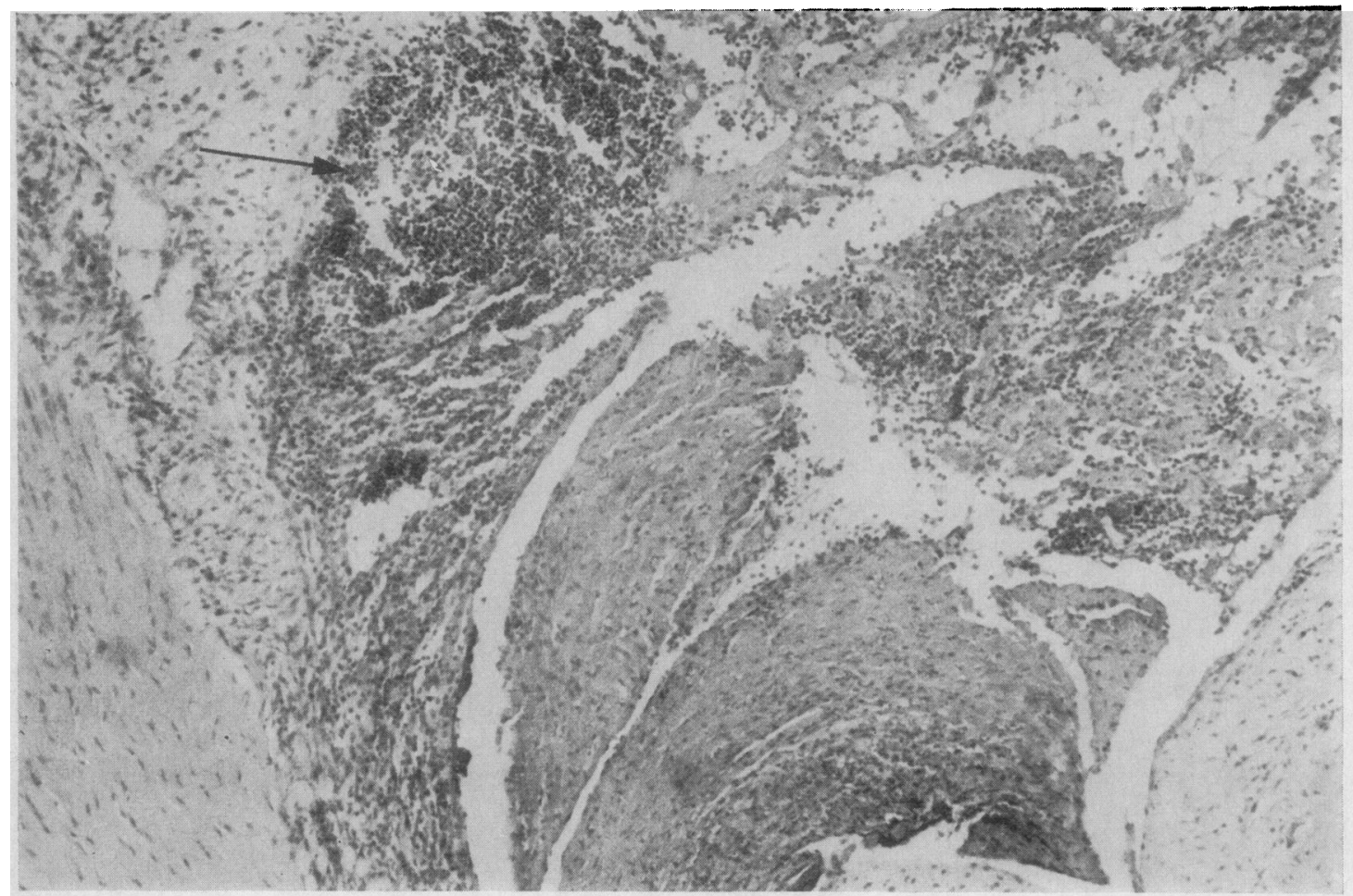

FIG. 5 Ankle joint from a normal mouse 6 days after M. pulmonis infection, in which there is periarticular round $\stackrel{\odot}{\mathbb{D}}$ cell infiltration and a micro-abscess (arrowed). $\times 125$

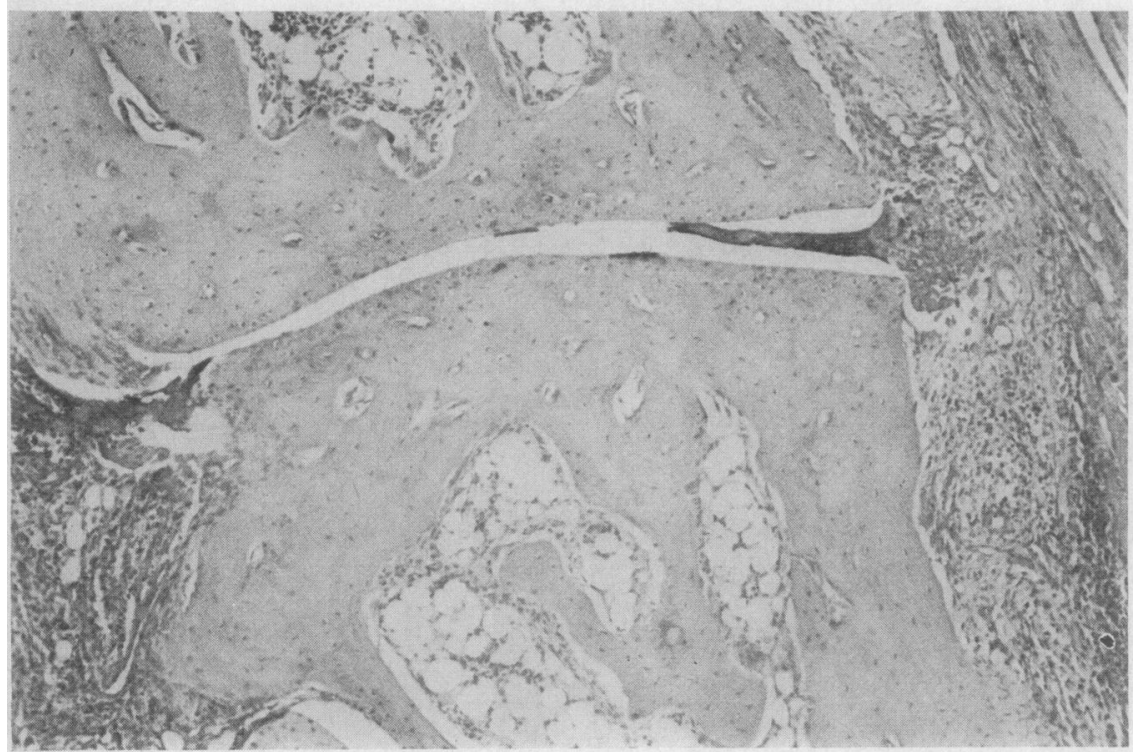

FIG. 6 Ankle joint from a normal mouse $\mathrm{O}$ 6 days after $\mathrm{M}$. pulmonis infection, in which $\frac{D}{0}$ there is periarticular round cell infiltration $N$ with minimal involvement of the joint space. $\times 93$

\section{EFFECT ON SURVIVAL OF MICE}

Most of the 15 mice that were given cyclophosphamide 24 hours after intravenous inoculation of M. pulmonis died within a week. Inoculation of even a relatively small number of organisms caused death
(Table III). Death also resulted when cyclophosphamide was given at any time between 3 days before and 2 days after mycoplasma inoculation. Infected, 8 but otherwise normal, and uninfected cyclophosphamide-treated mice survived. 
Table III Effect of cyclophosphamide on survival of mice infected 24 hours previously with $\mathrm{M}$. pulmonis

\begin{tabular}{|c|c|c|c|}
\hline \multirow[b]{2}{*}{ Experiment no. } & \multirow{2}{*}{$\begin{array}{l}\text { Inoculum } \\
\left(\log _{10} c c u / m l\right)\end{array}$} & \multicolumn{2}{|c|}{ No. of deaths/no. of mice inoculated* } \\
\hline & & Normal mice & Immunosuppressed mice \\
\hline $\begin{array}{l}1 \\
2 \\
3\end{array}$ & $\begin{array}{l}7 \cdot 3 \\
5 \cdot 3 \\
3 \cdot 3\end{array}$ & $\begin{array}{l}0 / 5 \\
0 / 5 \\
0 / 5\end{array}$ & $\begin{array}{l}4 / 5 \\
4 / 5 \\
5 / 5\end{array}$ \\
\hline
\end{tabular}

* 7 days after inoculation of M. pulmonis.

EFFECT ON THE ARTHRITIS SCORE

In another experiment, all of 15 immunologically normal mice developed arthritis during the 7-day period after the inoculation of $10^{6} \mathrm{ccu}$ of $M$. pulmonis. However, of 16 mice given cyclophosphamide 24 hours after infection, none of the 13 mice that were still alive at day 7 had developed arthritis. Further, cyclophosphamide given 2 days after infection also resulted in a marked suppression of arthritis (Fig. 7). However, by day 10, surviving mice had developed an arthritis comparable with that of the controls. In contrast to the suppression of arthritis seen when cyclophosphamide was given after the mycoplasma, a greater arthritis score was noted for mice treated with cyclophosphamide 3 days before infection.

\section{EFFECT ON HISTOPATHOLOGY}

Examination of sections of joints from mice immunosuppressed by giving cyclophosphamide 24 hours after mycoplasma infection revealed that there was a much less marked inflammatory response (Fig. 8) than seen in the joints of immunologically normal mice (Fig. 5). However, inflammation was still noted in the form of fibrinous exudates.

We were unable to find lesions likely to have caused death in any other tissues of the immunosuppressed mice.

EFFECT ON DISTRIBUTION AND NUMBER OF MYCOPLASMA ORGANISMS IN VARIOUS ORGANS The numbers of organisms isolated from mice treated with cyclophosphamide 24 hours after infection and from untreated but infected mice which were killed at various intervals after infection, are shown in Fig. 9. Each point on the graph represents 2-3 mice; though the numbers of mice are small, there is a difference in persistence of mycoplasmas in organs of mice in the two groups. Thus, mycoplasmas persisted for a longer time and in greater numbers in the liver and blood of immunosuppressed mice than in immunologically normal mice. In order to confirm this observation, a larger group of mice was examined. Thirty mice were each inoculated with approximately $10^{7} \mathrm{ccu}$ of $M$. pulmonis and half of them were given cyclophosphamide 24 hours later. At autopsy 6 days after infection, mycoplasmas were present in greater numbers in the blood, liver, spleen, brain, and joints of immunosuppressed mice than in comparable organs of immunologically normal mice (Table IV).

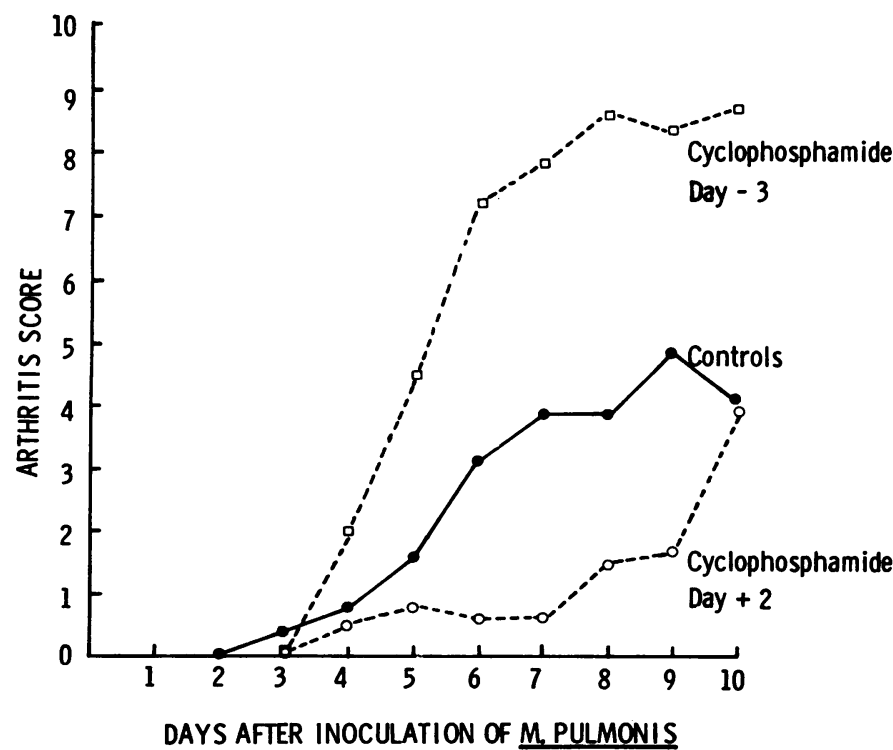

FIG. 7 Development of arthritis in mice treated with cyclophosphamide 3 days before or 2 days after inoculation of $10^{6} \mathrm{ccu}$ of $\mathrm{M}$. pulmonis 


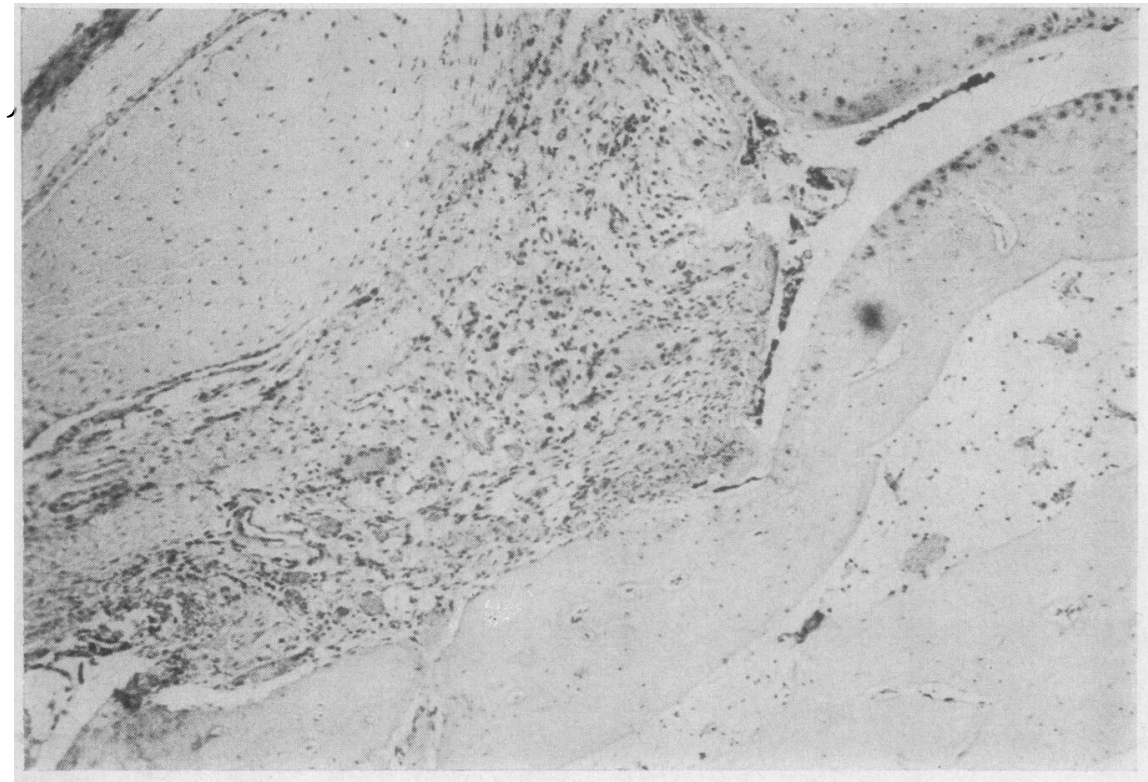

FIG. 8 Ankle joint from a mouse treated with cyclophosphamide 24 hours after M. pulmonis infection, in which there is little cellular infiltration. $\times 93$

Table IV Effect of cyclophosphamide on isolation of mycoplasmas from mice infected 24 hours previously with $\mathrm{M}$. pulmonis

\begin{tabular}{|c|c|c|}
\hline \multirow{2}{*}{$\begin{array}{l}\text { Organs } \\
\text { examined }\end{array}$} & \multicolumn{2}{|c|}{$\begin{array}{l}\text { Geometric mean of no. of organisms } \\
\text { isolated }\left(\log _{10} \mathrm{ccu} / \mathrm{ml}\right) \text { from }\end{array}$} \\
\hline & Normal mice & Immunosuppressed mice \\
\hline $\begin{array}{l}\text { Blood } \\
\text { Liver } \\
\text { Spleen } \\
\text { Brain } \\
\text { Joint }\end{array}$ & $\begin{array}{l}3.5 \\
3.9 \\
5 \cdot 6 \\
2.9 \\
4.9\end{array}$ & $\begin{array}{l}6 \cdot 2 \\
7.9 \\
7 \cdot 4 \\
6 \cdot 8 \\
7 \cdot 2\end{array}$ \\
\hline
\end{tabular}

\section{Metabolism-inhibition test on mouse sera}

To determine whether cyclophosphamide treatment had affected the titre of metabolism-inhibiting antibody to the 'JB' strain of $M$. pulmonis, sera taken 6 days after infection were examined using the 'JB' and 'Peter C' strains of M. pulmonis. Antibody was not demonstrated in any of the sera nor in immunoglobulins of the same sera which had been concentrated tenfold. Furthermore, antibody was not detected in the sera of immunologically normal but infected mice.

\section{Discussion}

It is known that the thymus-dependent (' $T$ ') lymphocyte population of mice is depleted by thymectomy, $x$-irradiation, or treatment with antilymphocyte serum, and there is evidence that thymus-independent ('B') lymphocytes are diminished in number by treatment of the animals with cyclophosphamide (Turk and Poulter, 1972). These methods of immunosuppression were used to investigate the role of ' $T$ ' and ' $\mathrm{B}$ ' cells in the development of arthritis in mice infected with the 'JB' strain of M. pulmonis.

Denny and others (1972) showed that pneumonic lesions induced in mice by intranasal inoculation of M. pulmonis were the result of a ' $T$ ' cell-mediated response. Their conclusions were based on the observation that depletion of the ' $T$ ' cell population by the procedures mentioned above caused a decrease in the severity of the pneumonic lesions. Singer, Ford, and Kirschstein (1972) found that treatment of infected mice with cyclophosphamide did not influence the severity of the pneumonia. This result is to be expected if the drug exerts its effect primarily on ' $B$ ' cells, and it indirectly confirms the importance of ' $T$ ' cells. However, the results of our experiments on arthritis due to $M$. pulmonis show a different pattern. Depletion of ' $T$ ' cells by thymectomy and $x$-irradiation was followed by a more severe arthritis than that seen in immunologically normal mice. In addition, organisms were isolated more frequently and joints were involved more often, so that it seems likely that a thymusdependent function plays some part in restricting the spread of mycoplasmas. On the other hand, ' $T$ ' cells are apparently a minor constituent of the cellular exudate.

Whether the arthritis is initiated by the presence within the joints of the organisms themselves or by antibody-mediated mechanisms such as the deposition of immune complexes is not known. Since the lymphocytes in the lesions were not affected by thymectomy, it seemed reasonable to suppose that thymus-independent lymphocytes were involved in 


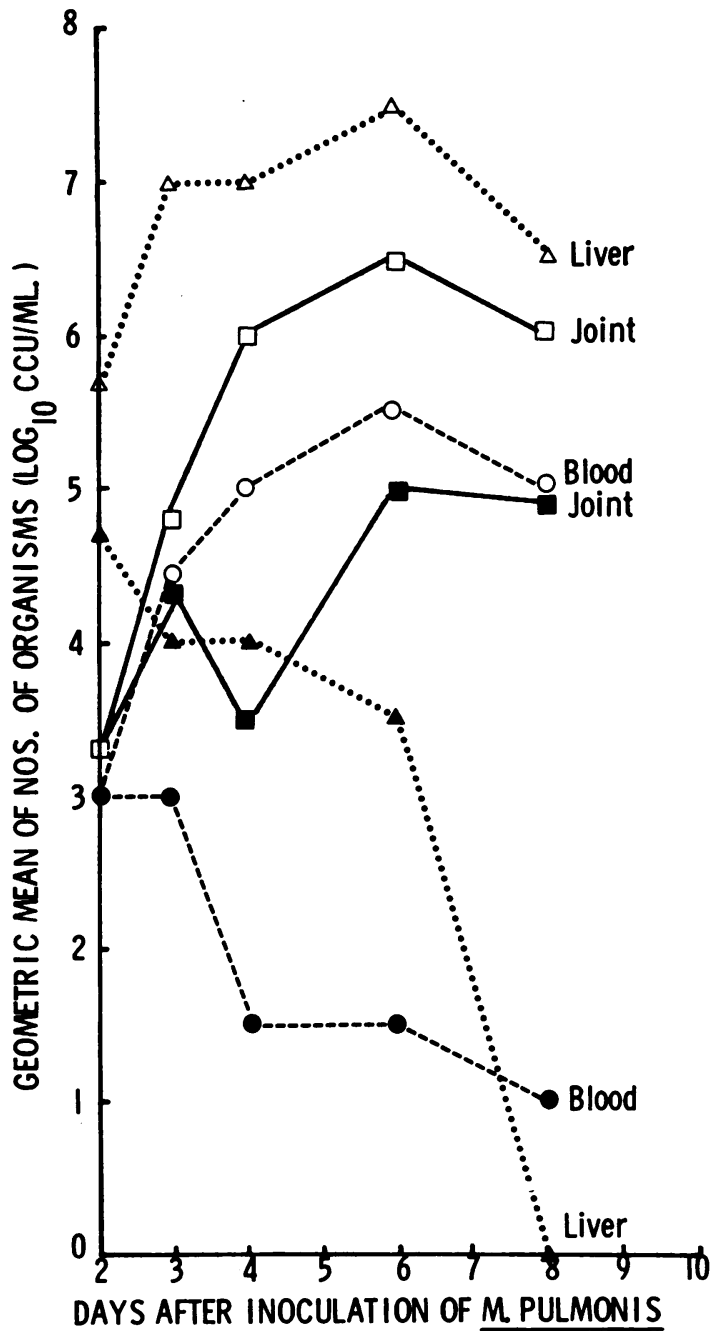

FIG. 9 Comparison of the numbers of $\mathrm{M}$. pulmonis organisms in tissues of normal infected mice (solid symbols) and mice treated with cyclophosphamide (open symbols) 24 hours after inoculation of $10^{6} \mathrm{ccu}$ of $\mathrm{M}$. pulmonis

the development of arthritis. We thought, therefore, that cyclophosphamide might suppress arthritis either by reducing the number of these cells in the lesions or by suppressing antibody production. Since the timing of cyclophosphamide administration in relation to antigen challenge is important (Santos, 1967; Rager-Zisman and Allison, 1973), we gave cyclophosphamide to some mice after, and to others before, mycoplasma inoculation. In both instances this resulted in death of mice, a feature observed by Singer and others (1972) when they gave mice cyclophosphamide 24 hours after intranasal inoculation of M. pulmonis. Although death of mice posed problems in assessing arthritis, we were able to show that the administration of cyclophosphamide 24 hours after intravenous inoculation of $M$. pulmonis greatly reduced the severity of the arthritis. Histologically this was seen as an almost total suppression of monocyte and polymorphonuclear leucocyte infiltration, though there was no inhibition of the early exudative inflammatory reaction because vascular dilatation and fibrin were still present. This is not surprising since cyclophosphamide acts, not solely on 'B' lymphocytes, but also on other rapidly dividing cells (Bruce, Meeker, and Valeriote, 1966). A decrease in cellular infiltration was also seen when cyclophosphamide was given 48 hours after the mycoplasma. In this instance, however, the mice survived sufficiently long for a later developing arthritis to be observed. Stockman, Heim, South, and Trentin (1973) found that ' $B$ ' cell responsiveness of mice recovered 10 to 14 days after cyclophosphamide treatment. If other cell populations affected by this drug recover at about the same time, this could account for the eventual appearance of arthritis. At first sight it seemed paradoxical that a more severe arthritis than usual should develop when cyclophosphamide was given 3 days before the mycoplasma. However, a possible explanation for this is that mycoplasmas increased in number as a result of the absence of defence mechanisms, stimulating a greater infiltration of cells when the cellular response recovered.

Cole, Golightly-Rowland, Ward, and Wiley (1970) failed to detect circulating antibodies to M.pulmonis and so did we even when we examined concentrated sera, though it must be admitted that early sera were tested and the method would not detect bound antibody. However, it is known that cyclophosphamide inhibits antibody production (Santos, 1967) and since the early stage of inflammation still occurred after treatment with cyclophosphamide, this appears to exclude the possibility of it being initiated by an antibody-mediated mechanism.

Barden and Tully (1969) observed that the arthritis produced by intravenous inoculation of $M$. pulmonis 'JB' was migratory, i.e. enlargement of the fore-feet occurred before that of the ankles, irrespective of the number of organisms inoculated. Further, they could not find histological evidence of microabscess formation in the joints at 2 weeks and 3 months after infection. In contrast, we did not see a migratory arthritis and we did find abscess formation during the 2-week period studied. Of course, different strains of mice may react differently. This early acute arthritis in mice closely resembles the arthritis produced in rats by intravenous inoculation of $M$. arthritidis (Findlay and others, 1939; Ward and Jones, 1962). It seems to us that the early arthritis in mice was not the result of thymus-dependent or antibody-mediated mechanisms but was probably a nonimmune inflammatory defence mechanism. However, the role of immune mechanisms in the chronic stage of the arthritis still requires evaluation. 


\section{Summary}

Immunologically normal $\mathrm{C} 3 \mathrm{H}$ mice developed a more severe arthritis than CBA mice after intravenous inoculation of the same number of $M$. pulmonis organisms. Increasing the number of organisms inoculated aggravated the arthritis and reduced the latent period. The arthritis was characterized by a mixed polymorphonuclear leucocyte and monocyte infiltration of periarticular tissues and was often suppurative. There was minimal joint-space involvement. In contrast to immunologically normal mice, those immunosuppressed by thymectomy and $x$-irradiation, and then infected with $M$. pulmonis, developed a more severe arthritis and a greater number of joints were involved. However, the main histological features of the arthritis were the same as those of infected, normal mice. The more severe arthritis was associated with an increase in the spread of mycoplasmas to joints and other tissues. This indicated that a thymus- $\frac{\mathrm{D}}{\mathrm{N}}$. dependent function prevents spread of organisms, but that ' $T$ ' lymphocytes are not involved in the arthritis $\stackrel{\vec{S}}{\vec{D}}$ lesion to any extent. Infected mice died after treat- $\square$ ment with cyclophosphamide and the organisms were isolated from their tissues in larger numbers than from those of untreated mice. The development of arthritis was delayed if cyclophosphamide was given after $M$. pulmonis; arthritis was more severe if the drug was given before the mycoplasma. Reasons for the different observations are discussed. It seems that the inflammatory reaction is probably not the result of a specific immune response but is more a nonspecific inflammatory defence mechanism.

We are grateful to Mr. G. F. Heath for technical assistance, and to the staff of the Department of Histopathology. G. T. holds an M.R.C. Scholarship for training in $\sigma$ research methods.

\section{References}

BARden, J. A., AND DeCKer, J. L. (1971) Arthr. and Rheum., 14, 193 (Mycoplasma hyorhinis swine arthritis)

BARDen, J. A., AND Tully, J. G. (1969) J. Bact., 100, 5 (Experimental arthritis in mice with Mycoplasma pulmonis)

Bruce, W. R., Meeker, B. E., AND Valeriote, F. A. (1966) J. nat. Canc. Inst., 37, 233 (Comparison of the sensitivity of normal hematopoietic and transplanted lymphoma colony-forming cells to chemotherapeutic agents administered in vivo)

Cole, B. C., Golightly-Rowland, L., Ward, J. R., and Wiley, B. B. (1970) Inf. and Imm., 2, 419 (Immunological response of rodents to murine mycoplasmas)

Cole, B. C., Ward, J. R., Jones, R. S., and Cahill, J. F. (1971) Med. Clin. N. Amer., 4, 344 (Chronic proliferative arthritis of mice induced by Mycoplasma arthritidis. 1. Induction of disease and histopathological characteristics)

Denny, F. W., Taylor-Robinson, D., and Allison, A. C. (1972) J. med Microbiol., 5, 327 (The role of thymusdependent immunity in Mycoplasma pulmonis infections of mice)

FabricANT, J. (1969) 'Avian mycoplasmas', in 'The Mycoplasmatales and the L-phase of Bacteria', ed. L. Hayflick, p. 621. Appleton-Century-Crofts, New York

Findlay, G. M., Mackenzie, R. D., MacCallum, F. O., and Klieneberger, E. (1939) Lancet, 2, 7 (The aetiology of polyarthritis in the rat)

Hannan, P. C. T. (1971) J. gen. Microbiol., 67, 363 (Observations on the arthritogenic properties of Sabin's type C murine mycoplasma (Mycoplasma histotropicum))

Olson, N. O., Kerr, K. M., And Campbell, A. (1964) Avian Dis., 8, 209 (Control of infectious synovitis. 13. The antigen study of three strains)

Rager-Zisman, B., AND Allison, A. C. (1973) J. gen. Virol., 19, 339 (Effects of immunosuppression on Coxsackie B-3 virus infection in mice, and passive protection by circulating antibody)

Ross, R. F., and Switzer, W. P. (1968) Med. Clin. N. Amer., 52, 677 (Mycoplasmal arthritis of swine)

Santos, G. W. (1967) Fed. Proc., 26, 907 (Immunosuppressive drugs)

Singer, S. H., Ford, M., AND KirSCHSTeIN, R. L. (1972) Inf. and Imm., 5, 953 (Respiratory diseases in cyclophosphamide-treated mice. 1. Increased virulence of Mycoplasma pulmonis)

Stockman, G. D., Heim, L. R., South, M. A., AND Trentin, J. J. (1973) J. Immunol., 110, 277 (Differential effects of cyclophosphamide on the B and $\mathrm{T}$ cell compartments of adult mice)

Switzer, W. P. (1969) 'Swine mycoplasmas', in 'The Mycoplasmatales and the L-phase of Bacteria', ed. L. Hayflick, p. 607. Appleton-Century-Crofts, New York

TAYlor, G., TAYLOR-Robinson, D., AND Fernald, G. W. (in press) (1974) J. med. Microbiol. (Reduction in the severity of Mycoplasma pneumoniae-induced pneumonia in hamsters by immunosuppressive treatment with anti-thymocyte sera)

Taylor-Robinson, D., Denny, F. W., Thompson, G. W., Allison, A. C., and Mårdh, P.-A. (1972) Med. Microbiol. Immunol., 158, 9 (Isolation of mycoplasmas from lungs by a perfusion technique)

-, Purcell, R. H., Wong, D. C., ANd Chanock, R. M. (1966) J. Hyg. (Camb.), 64, 91 (A colour test for the measurement of antibody to certain mycoplasma species based upon the inhibition of acid production)

Turk, J. L., AND Poulter, L. W. (1972) Clin. exp. Immunol., 10, 285 (Selective depletion of lymphoid tissue by cyclophosphamide)

WARD, J. R., AND Jones, R. S. (1962) Arthr. and Rheum., 5, 163 (The pathogenesis of mycoplasmal (PPLO) arthritis in rats) 